\title{
Determinants of adoption and intensity of improved faba bean cultivars in the central highlands of Ethiopia: a double-hurdle approach
}

Yehuala Kassa ${ }^{1 *} \mathbb{D}$, Almaz Giziew ${ }^{2} \mathbb{D}$ and Dereje Ayalew²

\begin{abstract}
Background: Faba bean (Vicia faba. L) is the most important pulse crop both in area coverage and volume of annual production in Ethiopia. However, productivity in terms of yield in Ethiopia is still far below its potential. One important reason is that farmers are largely dependent on their local landraces. Despite the release of about 34 improved faba bean cultivars, farmers' use of certified improved seeds is very low. This study, therefore, aimed to generate useful information on farmers' adoption of improved faba bean cultivars by identifying factors that determine a farmer's decision to use improved cultivars.
\end{abstract}

Methods: A multi-stage sampling technique was followed to select sample households. A cross-sectional household survey was used to collect data from 168 households that were randomly selected. Moreover, focus group discussions and key informant interviews were conducted. For data analysis, the Double-hurdle econometric model was employed.

Results: The results revealed that the majority, i.e., $77 \%$ of rural households depended on their local landraces. The adoption rate of improved faba bean seed at the household level was $23 \%$ which is very low. This low adoption rate was mainly due to a lack of access to improved seed and a lack of awareness about the improved cultivars. The results suggest that the decisions to adopt the improved cultivars and how much land to be covered appear to be explained by different processes. The double-hurdle econometric model result further revealed that while a farmer's adoption decision is influenced by family size, farmers' awareness about the existing improved cultivars, and extension contact, the intensity of adoption is determined by livestock holding and access to market information.

Conclusion: The result showed that most of the rural households were largely dependent on their local faba bean landraces which result in low yields at harvest. Therefore, it is suggested that the promotion of improved faba bean cultivars and improve farmers' access to extension service and timely market information are the most decisive factors to be emphasized to improve the adoption of improved cultivars.

Keywords: Adoption, Determinants, Double hurdle, Faba bean, Improved varieties

*Correspondence: yehuala13@gmail.com

${ }^{1}$ Debre Birhan Agricultural Research Center, Amhara Agricultural Research Institute, Debre Birhan, Ethiopia

Full list of author information is available at the end of the article

\section{Background}

Endowed with varied agro-ecological zones and diversified natural resources, Ethiopia has been a home for several species of crops. Pulses, which occupy approximately $13 \%$ of cultivated land and that account for approximately 
$10 \%$ of the agricultural value addition next to cereal crops are critical to smallholder livelihoods in Ethiopia (Rashid et al. 2010; CSA 2016). The major types of pulses grown include faba beans, chickpeas, haricot beans, lentils, dry peas, mung beans, and vetches.

Faba bean (Vicia faba $L$ ) is the first largest produced food legume globally (Gaur et al. 2010) and also the country is the second-largest producer of faba beans in the world next to China (Ronner and Giller 2012; Abebe et al. 2014). In Ethiopia, faba bean is the most important pulse crop both in terms of area coverage and volume of annual production (Hailu et al. 2014; CSA 2018a). At a national level, about 4,37,106 ha of land were covered annually by faba bean of which 3,682,512 smallholder farmers were engaged in growing the crop (CSA 2018a). Faba bean is a multi-purpose legume and leading protein source for the rural people in Ethiopia (Emiola and Gous 2011; Malunga et al. 2014; Sarker et al. 2014; Tekalign et al. 2016). As a potential rotational crop, it plays a key role in soil fertility improvement through nitrogen fixation (Agegnehu and Fessehaie 2006; Ronner and Giller 2012). Most importantly, it has been serving as a source of foreign currency to the country (Rashid et al. 2010; Thijs et al. 2015).

Despite its huge importance and area coverage, the productivity of faba bean is about 2.11 tonnes $\mathrm{ha}^{-1}$ (CSA 2018), far below the potential of the crop which was 5.2 tonnes $\mathrm{ha}^{-1}$ (MoARD 2008). This may be due to different biotic and abiotic factors: the use of old and low yielding local landraces and unavailability of the high yielder improved varieties (Alene et al. 2000; Dadi et al. 2005; Bishaw and Van Gastel 2008; Rashid et al. 2010; Anteneh et al. 2018); limited or no use of inorganic fertilizers (Asfaw et al. 2011) and the newly emerged faba bean gall disease (Hailu et al. 2014; Bitew 2015; Bitew and Tigabe 2016; Debela et al. 2017; Anteneh et al. 2018) might have been the most important factors.

The improved seed is one of the most important sources of innovation, particularly in resource-constrained small farm environments. Increasing, the quality of seeds can increase the yield potential of the crop many times over. This, in turn, is one of the most economical and efficient inputs to agricultural development (Messrs et al. 2007). To a large extent, the responses of all other inputs depend on the quality of seeds used. Through a combination of improved technologies and improved farmer cultivation practices, small-scale farmers in Ethiopia can produce higher yields from seeds of improved cultivars. According to ATA (2011), the use of improved seeds increases productivity by $50 \%$.

The pulse research program in Ethiopia has released several improved pulses cultivars including 34 faba bean cultivars (MoA 2018) which are aimed at increasing its productivity (Kemal et al. 2003). Despite the release of this large number of improved cultivars, the use of certified improved seeds by farmers is very low. Of the total annual arable land coverage by major food crops in 2010, only $3.5 \%$ were covered by improved seeds (Atilaw 2010). Similarly, it was found that only $0.8 \%$ of the total pulse cropped areas were covered by improved seed in the 2017/18 growing season (CSA 2018b). The inefficient and ineffective seed industry and unavailability of quality seeds at the right place and time coupled with poor promotion systems are key factors accounting for the limited use of improved faba bean seed (Atilaw 2010; Thijs et al. 2015).

The seed systems in Ethiopia can be divided into two broad but interacting seed delivery systems: the formal and the informal sector (Atilaw, 2010; ATA 2011). However, according to Bishaw and Van Gastel (2008), the formal seed sector supplied only $2 \%$ of the country's seed requirements. When disaggregated by crop type, cereals accounted for about $80 \%$ of the total cultivated area followed by pulses and oilseeds with $13 \%$ and $7 \%$ of area coverage, respectively. Therefore, the informal seed sector remains the major source of faba bean seed for the farming community. Traditionally, the informal seed system in the Ethiopian context is defined as seed production and distribution practices where the practice has not given any legal seed certification (Alemu et al. 2010). According to Atilaw and Korbu (2011), farmer's own saved seed and farmer to farmer seed exchange explained more than $95 \%$ of the seed used by farmers. Nonetheless, in recent years, the thought of an integrated seed system has appeared within the Ethiopian seed sector (Atilaw and Korbu 2011). It combines attributes of both the formal and the informal seed systems. Specifically, the intermediate sector is defined as business-oriented community-based groups (seed producers and marketing cooperatives or unions) that are engaged in the multiplication and distribution of non-certified seeds of either modern or local varieties (ATA and MoA 2013). This paper, therefore, aimed to identify factors that determine farmers' access to using improved faba bean seed.

\section{The methodology of the Study \\ Description of the study area}

The study was conducted at Basona Werana District which is found at the eastern edge of the Ethiopian highlands in the North Shewa Zone of Amhara Regional State. It is located about $130 \mathrm{~km}$ north of Addis Ababa. The district is located between $9^{\circ} 49^{\prime} 59.99^{\prime \prime}$ Northern latitude and $39^{\circ} 19^{\prime} 60.00^{\prime \prime}$ Eastern longitude. The altitude of the district ranges between 2800 and $3000 \mathrm{~m}$ above sea level while the annual temperature varies from 9 to $15^{\circ} \mathrm{C}$. The mean annual rainfall ranges from 900 to $1500 \mathrm{~mm}$ 
and topographically the district is largely mountainous with escarpments covered predominantly with reddishbrown soil.

The area's production system is a mixed crop-livestock agricultural system whereby smallholder farmers practice crop and livestock production. The major crops grown include tef (Eragrostis tef), barley (Hordeum Vulgare $L$ ), wheat (Triticum), faba bean (Vicia faba L), field pea (Pisum sativum), chickpea (Cicer arietinum), and lentil (Lens culinaris). Among the major pulse crops, land covered by faba bean is important which is produced both as a cash crop and for household consumption. Cattle, goats, sheep, equines, and poultry are also important domestic animals kept by the smallholder farmers integrated with crop production. Thus, both crop and livestock contribute their share to the farmers' agricultural income.

Data

This study mainly utilized a quantitative method of data gathering techniques. The data for this cross-sectional study was obtained through a farm household survey which was administered on randomly selected smallholder farmers drawn by multistage sampling techniques. In the first stage, the Basona Werana district was selected purposely based on its production potential. In the second stage, three kebele ${ }^{1}$ were selected again on purpose based on the production potential of the crop. Finally, sample households were drawn from each kebele using a systematic random sampling technique. The primary sampling units were the households that grew faba beans during the data collection period, 2018 main growing season. The list of the household was obtained from the kebele agricultural office. The sample size for the study was determined based on the following formula given by Kothari (2004).

$$
n=\frac{z^{2} \cdot p \cdot q \cdot N}{e^{2}(N-1)+z^{2} \cdot p \cdot q}
$$

where: $\mathrm{n}$ is the desired sample size, $\mathrm{N}$ is the total faba bean grower household of the selected kebele, $\mathrm{z}$ is the value of the standard variant at $95 \%$ confidence level and to be worked out from a table showing the area under the normal curve $(\mathrm{z}=1.96)$, $\mathbf{e}$ is the level of precision $= \pm 6 \%$, $\mathrm{p}=23 \%$ and $\mathrm{q}=(1-\mathrm{p})$.

By using the above formula, a total of 168 sample respondents were selected and allocated proportionally depending on the probability proportional to the size of each kebele. Details of the sampling design are summarized in Table 1 below.

\footnotetext{
${ }^{1}$ It is usually named as a peasant association and is the lowest administrative unit in the country.
}

Table 1 Distribution of sampled households in the three selected kebele. Source: Kebele office of agriculture report, 2018

\begin{tabular}{llll}
\hline Kebele & $\begin{array}{l}\text { Number of total } \\
\text { households }\end{array}$ & $\begin{array}{l}\text { Sample } \\
\text { households }\end{array}$ & $\begin{array}{l}\text { \% share of } \\
\text { the total } \\
\text { sample }\end{array}$ \\
\hline Bakelo & 527 & 57 & 33.9 \\
Gudoberet & 571 & 62 & 36.9 \\
Weshawushign & 457 & 49 & 29.2 \\
Total & 1555 & 168 & 100 \\
\hline
\end{tabular}

The collected data include demographic characteristics, i.e., sex of the household head, family size, farming experience; socioeconomic conditions such as education status, landholding, land allocated for faba bean production, livestock holding, access to credit service, availability of improved cultivars, access to improved seed, cost of seed, and market price after harvest; institutional factors including access to extension services, market information, memberships to different formal and informal institutions, home residence distance to the main market, farmer training center, and multi-purpose cooperatives.

Farmers' decisions about whether and how to adopt new technology are conditioned by the dynamic interaction between characteristics of the technology itself and the array of conditions and circumstances (Loevinsohn et al. 2012; Biagini et al. 2014). Adopters are defined as households that plant an improved faba bean variety. As our measure of adoption in the econometric models, we use the area allocated to improved varieties as an indicator for the extent or scale of adoption.

There exists a vast body of literature on factors that determine agricultural technology adoption. Access to improved seeds and faba bean technology transfer are important preconditions for adoption. Adoption of improved varieties depends on the availability and accessibility of improved seeds (Abera 2008; Asfaw et al. 2012), which is a concern in our context. Often cited factors used to explain adoption are age, family size, farming experience, landholding, livestock holding, awareness about the availability of improved cultivars, farming experience, availability of family labor, frequency of extension contact, access to credit service, home residence distance to the local market and agricultural offices, and membership in farmers associations (Feder et al. 1985; Alene et al. 2000; Sunding and Zilberman 2001; Dadi et al. 2005; Abera 2008; Shiferaw et al. 2008; Foster and Rosenzweig 2010; Asfaw et al. 2011; Beshir et al. 2012; Alemaw 2014; Challa and Tilahun 2014; Hailu et al. 2014; Krishnan and Patnam 2014; Weyessa 2014; Awesa 2015; Yirga et al. 2015; Verkaart et al. 2017; Chandio and Yuansheng 2018; Zeng et al. 2017). 


\section{Method of data analysis}

The data analysis techniques involved both descriptive and econometric analyses. Primary data collected from individual respondents through the formal survey were analyzed using descriptive statistics such as simple measures of central tendency, frequency, and percentages.

To detect the degree of relationships between some quantifiable explanatory variables measured and the dependent variable, the Double-hurdle econometric model was employed. Farmers' decision to adopt improved varieties is contingent upon the farmer or farm-specific attributes; therefore, their adoption is a self-selection process instead of a random-assignment process. Let $U_{i A}$ and $U_{i N}$ be the farmer I's utilities from the adoption and non-adoption of the improved varieties, respectively. Farmers will decide to adopt the improved varieties when $U_{i}^{*}=U_{i A}-U_{i N}>0$. However, farmers' utility from the adoption of improved varieties is unobserved. As suggested by Ali and Abdulai (2010), Asfaw et al. (2011), and Kassie et al. (2011), the adoption decision can be modeled using a random utility framework and expressed as a function of the observed variables as follows:

$$
\begin{aligned}
& U_{i}^{*}=\beta X_{i}+\varepsilon_{i} \\
& U_{i}=1 \text { if } U_{i}^{*}>0 \text { and } U_{i}=0 U_{i}^{*}<0
\end{aligned}
$$

where $U_{i}^{*}$ is a latent variable representing farmer i's adoption of the improved cultivars; it equals 1 if the farmer adopts and 0 otherwise. $X_{i}$ is the vector of observed variables that affect the probability of adoption.

In our sample data, there are both adopters and nonadopters of the improved varieties, while the adopters have different intensities of adoption. In other words, the adoption variable equals zero when the farmers do not adopt the improved faba bean cultivars, but this variable takes a positive continuous value when the farmers adopt these improved cultivars. In this case, the Tobit or the double-hurdle model may be appropriate (Mason and Smale 2013). The adoption of the improved faba bean cultivars may entail a two-stage decision-making process, including whether to adopt and then how much to adopt. These decisions can be simultaneously or separately determined. The Tobit model may be applied when these decisions are simultaneously determined. Meanwhile, the double-hurdle model may be more appropriate when these adoption decisions are made separately (Tambo and Abdoulaye 2012). The double-hurdle model is considered as a generalized and improved form of the Tobit model. The model is expressed using Eq. (2) for the first stage (decision on whether to adopt or the probability of adoption) and the following function for the second stage (decision on how much to adopt or the intensity of adoption):

$$
\begin{aligned}
& Y_{i}^{*}=\beta Z_{i}+\varepsilon_{i} \\
& Y_{i}=\left\{\begin{array}{l}
Y_{i}^{*} \text { if } Y_{i}^{*}>0 \\
0 \text { Otherwise }
\end{array}\right.
\end{aligned}
$$

$Y_{i}^{*}$ is the latent variable that denotes the farmer i's actual intensity of adoption and is measured, in this research, using the proportion of the area of land devoted to the improved faba bean cultivars. $Z_{i}$ is a vector of observed variables that explain the intensity of adoption.

In the first stage of the model, the Probit or Logit estimation may be employed to estimate the probability of adoption (Langyintuo and Mungoma 2008). In the second stage, several estimation techniques are suggested to estimate the intensity of adoption, including Truncated regression (Detre et al. 2011; Ricker-Gilbert et al. 2011), OLS regression (Cragg 1971), or Tobit (1958). This article applies the Probit and Truncated regressions to examine the farmers' adoption decisions in the first and second stages of the double-hurdle model, respectively (Cragg 1971).

Both the Double-hurdle and Tobit's model output was presented in this article for a comparison to determine which model best fits the data used for analysis. The likelihood ratio (LR) test was applied to investigate whether farmers make two-stage decisions simultaneously or separately. The LR test makes comparisons of the log-likelihood values from the double-hurdle model and Tobit models. The LR test will be conducted using the following equation:

$$
\lambda=-2\left(L L_{T}-L L_{P}-L L_{T R}\right)
$$

where, $\mathrm{LL}_{\mathrm{T}}$, $\mathrm{LL}_{\mathrm{P}}$, and $\mathrm{LL}_{\mathrm{TR}}$ denote the log-likelihood values for the Tobit, Probit, and Truncated models, respectively. $\lambda$ is an LR statistic value with Chi-square distribution with degrees of freedom equal to the number of independent variables. $\lambda$ is estimated under the null hypothesis that the Tobit model is more appropriate than the double-hurdle model. Consequently, the rejection of the null hypothesis means that the double hurdle model is a better alternative to fit the data.

\section{Results and Discussion \\ Socio-economic and demographic characteristics of sampled households}

Table 2 presents the demographic, socioeconomic, and institutional household characteristics. The proportion of female-headed households constituted $11.3 \%$ of the total sample households. In terms of literacy, the typical farmer in the sample had 4.1 years of schooling and 
Table 2 Summary of explanatory variables as entered the model

\begin{tabular}{|c|c|c|c|c|}
\hline Variables & Unit & Non-adopter & Adopter & Total \\
\hline Number of farmers & Number & 129 & 39 & 168 \\
\hline Male headed households & Number & 114 & 35 & 149 \\
\hline Female-headed households & Number & 15 & 4 & 19 \\
\hline Age of the respondent & Years & 46.33 & 46.85 & 46.27 \\
\hline Formal education & Years & 4.21 & 3.89 & 4.08 \\
\hline Farming experience in growing faba bean & Years & 21.45 & 21.74 & 21.53 \\
\hline Family size & Adult equivalent ${ }^{\mathrm{a}}$ & 4.41 & 4.17 & 4.26 \\
\hline Average livestock holding & TLU ${ }^{b}$ & 5.52 & 5.87 & 5.39 \\
\hline Total owned land & $\mathrm{Ha}$ & 1.39 & 1.59 & 1.44 \\
\hline Area of land covered by faba bean & $\mathrm{Ha}$ & 0.34 & 0.39 & 0.35 \\
\hline Plot distance (walking distance) & Minutes & 17.41 & 14.62 & 16.78 \\
\hline Access to improved seed (yes) & Frequency & 9 & 13 & 22 \\
\hline Extension contact & No. of days year ${ }^{-1}$ & 2.13 & 8.49 & 3.61 \\
\hline Farmers awareness about the existing varieties (yes) & Frequency & 65 & 36 & 101 \\
\hline Access to training on faba bean agronomy (yes) & Frequency & 46 & 21 & 67 \\
\hline Participation in field visit/field day (yes) & Frequency & 6 & 1 & 7 \\
\hline Access to market information (yes) & Frequency & 95 & 28 & 123 \\
\hline Seed cost during planting & ETB kg ${ }^{-1}$ & 15.68 & 15.71 & 15.69 \\
\hline Marketing price after harvesting & ETB kg ${ }^{-1}$ & 14.45 & 16.00 & 14.86 \\
\hline Membership to local primary cooperative (yes) & Frequency & 76 & 21 & 97 \\
\hline Membership to SPMCs (yes) & Frequency & 4 & 5 & 9 \\
\hline Access to credit (yes) & Frequency & 102 & 25 & 127 \\
\hline Home residence distance from a cooperative & Minutes & 50.68 & 45.1 & 49.4 \\
\hline Home residence distance from FTC & Minutes & 43.55 & 42.0 & 43.2 \\
\hline Home residence distance from the main market & Minutes & 106.7 & 112.75 & 108.1 \\
\hline
\end{tabular}

SPMCs stands for seed producer and marketing cooperatives

${ }^{a}$ Calculated following Storck et al. (1991) conversion factor

${ }^{\mathrm{b}} \mathrm{TLU}$ includes the following livestock types (conversion factors in parentheses): cattle (0.7), donkeys (0.5), horse (0.8), mule (0.7), sheep and goats (0.1), and chicken (0.01) (Harvest Choice 2015)

21.5 years of farming experience. The family size of the sample respondents ranged from 1 to 12 persons, with an average family size of 4.3 in adult equivalent. On average, the landholding size per household was found to be 1.44 hectares. Furthermore, livestock rearing was an important occupation and source of income for farm households. Moreover, on average, the sampled households were owned 5.39 TLU (tropical livestock unit) of livestock. The survey result further revealed that more than half of the respondents did not have any extension contact, particularly about faba bean production. The participants had, on average, 3.6 days per year extension contacts on the subject of faba bean production, agricultural training, farm visit by development agents, and farmer field days were the way through which the participants trained about agricultural extension services. Mean distance traveled to the nearest main market, farmer training center (FTC), and to multipurpose primary cooperatives were found to be 108.1, 43.2, and $49.4 \mathrm{~min}$ within walking distance (Table 2).

\section{Adoption of improved cultivars and current production status of faba bean}

Faba bean is one of the most important pulse crops next to barley and wheat, both in terms of area coverage and volume of production. The mean faba bean farm size of the sampled household was on average 0.35 ha with a share of $18.4 \%$ of their total cultivated land (Table 2). The improved cultivars of Walki, Dosha, Gebelicho, Dagim, and Lalo were among the improved faba bean cultivars introduced in the area. The widely adopted improved faba bean variety was Walki followed by Dosha variety. The reasons why adopters preferred these varieties included higher yield (75.6\%), resistance to diseases (16\%), and better market acceptance (8.4\%) compared to the local landraces.

Out of the total 168 sampled households, 39 (23.2\%) of them were found to be adopters of the improved faba bean cultivars which we consider as being very low. This low level of adoption of improved faba bean cultivars might probably be attributed to a lack of access to 


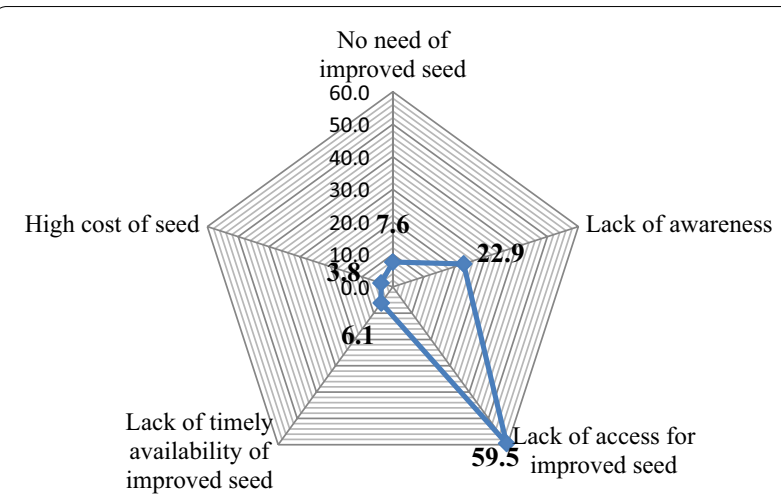

Fig. 1 Reasons (percent) for not using improved seed

improved seed, lack of awareness about the availability of improved cultivars, lack of timely availability, and high cost of improved seed (Fig. 1). On the other hand and most importantly a few of the participants, households, mentioned that the local landraces were preferable over-improved cultivars for their good shiro ${ }^{2}$ quality and better adaptability to the area. The result was in agreement with Dadi et al. (2005) and Asfaw et al. (2011) who mentioned the unavailability of improved seed and lack of awareness as the two most important constraints that explained the low rate of adoption of improved chickpea varieties. Alene et al. (2000) also reported that the availability of improved maize seed at the right time and in the required quantity had a significant influence on the adoption and level of use of improved maize varieties.

In the study area, the farmers' most important source of planting material was their own-saved seeds. The informal seed sector was found that the main source of faba bean seed constituted more than $97 \%$ of the seed used by the households in the 2018 growing season. As revealed below in Fig. 2, from the total respondents, about $70 \%$ use their own saved seed from the previous harvest whereas about $11 \%$ and $10 \%$ of them accessed it from their neighbors through farmer to farmer seed exchange systems and directly buying from the local market, respectively.

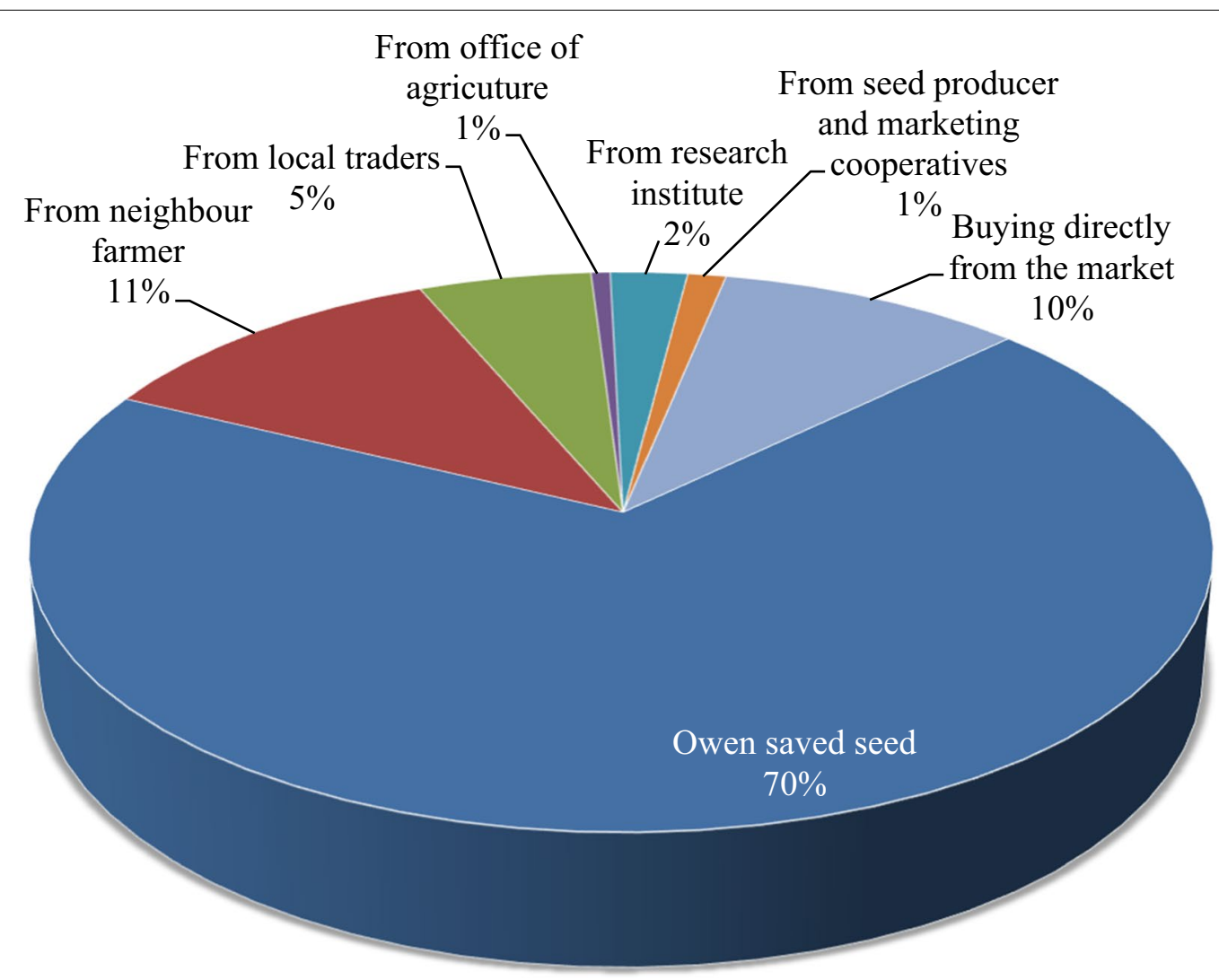

Fig. 2 Farmers'sources of seed

${ }^{2}$ It is one of Ethiopia's most famous dishes and is an essential part of the Ethiopian cuisine. Shiro is a homogeneous stew whose primary ingredients are powdered chickpeas, field peas, or a broad bean meal. 
Table 3 Estimates from the Double-hurdle and Tobit models

\begin{tabular}{|c|c|c|c|c|c|c|c|c|c|}
\hline \multirow[t]{3}{*}{ Variables } & \multicolumn{6}{|c|}{ Double hurdle model } & \multirow{2}{*}{\multicolumn{3}{|c|}{ Tobit model }} \\
\hline & \multicolumn{3}{|c|}{ Probit (first hurdle) } & \multicolumn{3}{|c|}{ Truncated regression (second hurdle) } & & & \\
\hline & Coef & Std. Err & $\mathrm{ME}^{\mathrm{a}}$ & Coef & Std. Err & $\mathrm{ME}^{\mathrm{a}}$ & Coef & Std. Err & $\mathrm{ME}^{\mathrm{a}}$ \\
\hline Sex & 0.2869854 & 0.4256422 & 0.0760568 & -0.0329689 & 0.125927 & -0.0280205 & 0.1036405 & 0.1837587 & 0.0200052 \\
\hline Formal education & -0.0169693 & 0.0464973 & -0.0044972 & -0.0250121 & 0.0225784 & -0.0212579 & -0.0147201 & 0.0211537 & -0.0028413 \\
\hline Family labor & $-0.2269943^{* *}$ & 0.1074657 & -0.060158 & 0.0507435 & 0.039978 & 0.0431272 & $-0.0986286^{* *}$ & 0.0468295 & -0.0190377 \\
\hline Farming experience & 0.0011544 & 0.0116634 & 0.0003059 & 0.001163 & 0.0039658 & 0.0009884 & 0.0008723 & 0.0049594 & 0.0001684 \\
\hline Land holding & 0.3060457 & 0.2212624 & 0.0811082 & 0.0728543 & 0.0805276 & 0.0619194 & $0.159442^{*}$ & 0.0950534 & 0.0308341 \\
\hline Plot distance & -0.0053713 & 0.065303 & -0.0014235 & 0.0022143 & 0.0019495 & 0.0018819 & -0.0010421 & 0.0027174 & -0.0002012 \\
\hline Livestock holding & 0.078225 & 0.0728454 & 0.0207312 & $0.0879935^{* * *}$ & 0.0262636 & 0.0747863 & $0.0644794^{* *}$ & 0.0327101 & 0.0124461 \\
\hline $\begin{array}{l}\text { Awareness on the exist- } \\
\text { ing varieties }\end{array}$ & $0.9191776^{* * *}$ & 0.3389331 & 0.2436004 & -0.1072093 & 0.1134118 & -0.0911179 & $0.343249^{* *}$ & 0.1492939 & 0.0662555 \\
\hline Extension contact & $0.0583659^{* * *}$ & 0.201247 & 0.0154681 & -0.001078 & 0.0055429 & -0.0009162 & $0.0203631^{* *}$ & 0.0081295 & 0.0039306 \\
\hline $\begin{array}{l}\text { Access to extension } \\
\text { training }\end{array}$ & -0.1366513 & 0.3211808 & -0.0362153 & 0.1896591 & 0.1522681 & 0.1611927 & -0.0241896 & 0.1378047 & -0.0046692 \\
\hline Field visit & -0.8949538 & 0.6967469 & -0.2371806 & -0.3800509 & 0.2848946 & -0.3230081 & -0.4264866 & 0.325775 & -0.0823224 \\
\hline $\begin{array}{l}\text { Access to market } \\
\text { information }\end{array}$ & -0.2328211 & 0.3054916 & -0.0617022 & $0.2696939^{* *}$ & 0.1177635 & 0.2292148 & -0.1936956 & 0.1342198 & -0.037388 \\
\hline $\begin{array}{l}\text { Membership to local } \\
\text { cooperative }\end{array}$ & -0.0805316 & 0.2726361 & -0.0213425 & 0.1116632 & 0.0917326 & 0.0949034 & -0.0049519 & 0.12057 & -0.0009558 \\
\hline Membership to SPMCs & 0.821393 & 0.5622672 & 0.2176855 & -0.0652477 & 0.1902271 & -0.0554545 & 0.2176841 & 0.2379834 & 0.0420184 \\
\hline Distance to FTC & -0.0011356 & 0.0054248 & -0.000301 & 0.0015939 & 0.0020142 & -0.0013547 & -0.0000376 & 0.002404 & \\
\hline $\begin{array}{l}\text { Distance to coopera- } \\
\text { tives }\end{array}$ & -0.0016718 & 0.0057493 & -0.000443 & -0.0004395 & 0.0028123 & -0.0003735 & -0.0015406 & 0.0026186 & -0.0002974 \\
\hline $\begin{array}{l}\text { Distance to local } \\
\text { market }\end{array}$ & -0.0010882 & 0.0021334 & -0.002884 & -0.0007033 & 0.0007756 & -0.0005977 & -0.0006117 & 0.000959 & -0.0001181 \\
\hline Access to credit & -0.3346575 & 0.3175017 & -0.0886909 & 0.1212993 & 0.1194104 & 0.1030932 & -0.113494 & 0.1410871 & -0.0219071 \\
\hline Availability of seed & -0.010581 & 0.0206321 & -0.0028042 & -0.1618653 & 0.1020231 & -0.1375705 & -0.0061212 & 0.0099096 & -0.0011815 \\
\hline Constant & -0.5980807 & 0.8042091 & & -0.2450028 & 0.3641673 & & -0.4097504 & 0.3642489 & \\
\hline Sigma & & & & 0.1845311 & 0.0258182 & & 0.4901377 & 0.0649235 & \\
\hline Log-Likelihood & -68.536573 & & & 19.207971 & & & -69.361309 & & \\
\hline \multicolumn{10}{|c|}{ Likelihood ratio test: Tobit Vs Double-hurdle $\lambda=40.07^{* * *}$} \\
\hline Obs & 168 & & & 39 & & & 168 & & \\
\hline
\end{tabular}

${ }^{a}$ ME denotes the marginal effect of the explanatory variables and is calculated at the sample mean

***, ${ }^{* *}$ and ${ }^{*}$ indicates the corresponding coefficients are statistically significant at $p<0.001, p<0.05$, and $p<0.1$, respectively

\section{Econometric result and determinants of improved seed utilization and intensity}

Table 3 presents the estimates from both the Doublehurdle and Tobit models. Before running the fitted Model, the existence of multicollinearity or association among the hypothesized explanatory variables was tested. Consequently, the results showed that all the continuous and dummy explanatory variables had no serious multicollinearity and autocorrelation problem. In this study, a likelihood ratio test with a value of $40.07(\mathrm{p}<0.01)$ rejects the null hypothesis of the model equivalence between the Tobit and the Double Hurdle econometric models. The results of the likelihood ratio test favor the use of the double-hurdle model which confirmed that farmers make decisions on whether to adopt the improved faba bean varieties and how much to adopt separately. Hence, in the next subsections, the interpretation and discussion will be relying on the estimated results from the Double-hurdle model.

\section{Determinants of the likelihood of adoption decision}

The first three columns of Table 3 present the estimated results from the Probit model. About 19 explanatory variables were included in the fitted model and only three of them were found to have a significant effect on the households' adoption decision of the improved faba bean cultivars. Factors that significantly explain the farmers' decision in the first stage include family size, farmers' awareness about the existing improved faba bean varieties, and extension contact.

Farmers' knowledge of the available improved varieties is an important factor for the adoption to take place. To adopt the newly introduced cultivars, farmers need to 
be aware of the available cultivars as adoption is sometimes hampered not only by the inherent characteristics of the cultivars but also by a lack of awareness of the end-users use of appropriate technologies. Farmers will require the necessary information to assess the suitability of the technology for their farming system and to understand the potential risks associated with the use of the technology. Awareness of smallholder farmers about the existing improved faba bean cultivars had a positive association with the adoption decision. Those farmers who knew more about improved cultivars probably have better information about the advantages of the cultivars and are more likely to adopt the new cultivars. The awareness level of farmers about improved cultivars affected adoption decisions positively at $\mathrm{p} \leq 0.01$ significance level. The marginal effect shows access to information about the existing improved faba bean cultivars increased the likelihood of adoption by 24.4 percentage points. This finding agreed with the results of Shiferaw et al. (2008) and Asfaw et al. (2011), who reported that knowledge of the existing varieties was among the important factors which determined agricultural technology adoption. Dadi et al. (2004) and Diagne and Demont (2007) also reported that, in most cases, exposure to technology is not random, and technology awareness is an important precondition for adoption to occur.

Farmers who had more frequent contact with extension agents were more likely to adopt the improved technologies as compared to farmers who had low frequent contact. The agricultural extension service was associated with the likelihood of adoption positively and significantly, at $\mathrm{p} \leq 0.01$ significance level. The marginal effects of this variable showed that farmers who had additional one-day contact with extension agents effects adoption decisions by 1.5 percentage points. This result is supported by previous findings of Krishnan and Patnam (2014), Verkaart et al. (2017), and Chandio and Yuansheng (2018), who suggested that technology transfer activities provided by the extension agents in Ethiopia assisted to transmit information vital to farmers in the early stages of adoption. Dadi et al. (2005) also explained that farmers, who participated in on-farm trials, demonstration, and farmer research groups, adopted improved chickpea varieties more than others did. In contrary to this result, the findings of Yigezu et al. (2015) showed that extension service is found to be insignificant in both crop choice and variety of adoption decisions.

Family size was found to influence a households' adoption decision negatively and significantly, at $\mathrm{p}<0.05$. As illustrated in Table 3 , it was found that the marginal effect of family size on farmers' decision to utilize improved cultivars was -0.06 . The negative association appears to suggest that the probability to adopt the improved cultivars tends to decline by 6 percentage points for each additional family size in terms of adult equivalent. This result is consistent with the results of Abera (2008) that family size was found to significantly and negatively influence the intensity of use of inorganic fertilizer at below $1 \%$ level of significance. A similar result was also reported by Challa and Tilahun (2014) who found the negative influence of large family size on the adoption of modern agricultural technologies. Unlike the above-mentioned findings, many of the previous studies emphasized the importance of available family labor for improved technology adoption (see for example Alene et al. 2000; Asfaw et al. 2011; Alemaw 2014).

Labor availability is an often-mentioned variable that affects farmers' decisions regarding the adoption of new agricultural practices or inputs. Family labor is one of the most important inputs to smallholder farm production (White et al. 2005). Higher family labor supply is associated with higher rates of adoption of labor-intensive technologies (Feder et al. 1981). Farmers with limited resources often struggle to supply sufficient labor to meet periodic labor demands that arise from seasonal-specific cultivation patterns. On the other hand, household members are both production and consumption units. When there are fewer opportunities to contribute to improving productivity, household units will be more consumption units. Some new technologies are relatively labor-saving, and others are labor-intensive. Labor requirements for adopting the improved technology will largely depend on the nature of the technology. For example, row planting of tef is labor-intensive, and its adoption might be discouraged by the labor shortage (Vandercasteelen et al. 2018). A simple move from local faba bean varieties to improved faba bean varieties would not necessitate additional labor. Households with larger extended families, on the other hand, could be intended to diversify their sources of income. Some family members may be engaged in offfarm and non-farm income-generating activities and thus may not be directly involved in the farming activities of the family. All the household members may not actively be involved and have no equal contributions in the farm operation activities of land preparation, planting, weeding, harvesting, and trashing.

\section{Determinants of the intensity of adoption of improved faba bean cultivars}

The estimates of the second hurdle using Truncated Regression are reported in columns 4, 5, and 6 of Table 3. In the second stage, the effects and the sign of some explanatory variables were changed. Indeed, it is documented in the literature that the estimates in the first stage may vary from those in the second stage (Asfaw et al. 2011; Ricker-Gilbert et al. 2011). Among the 
explanatory variables, only livestock holding and access to market information were found to significantly determine the intensity of adoption of the improved faba bean cultivars.

Examining the other variables in the double hurdle model, the extent of adoption, but not adoption, is positively and significantly correlated with livestock holding at $\mathrm{p} \leq 0.01$ probability level. This result indicates that while additional livestock holding may or may not influence adoption, households with more livestock devote a larger proportion of land to improved faba bean cultivars. The marginal effect result revealed that an increase in one unit of tropical livestock unit would increase the area devoted to the improved faba bean cultivars by 0.07 ha. The result could be explained as better risk-bearing behavior of those wealthy farmers with better livestock would enable them to try those newly adopted faba bean varieties. The result was in line with the work of Asfaw et al. (2011) who mentioned that livestock holdings had a positive and significant association with the adoption of improved chickpea varieties. In a similar vein, Alemaw (2014) reported that a positive and significant association of livestock holding showed on the adoption of improved maize varieties.

Mixed crop-livestock production is the dominant farming system whereby farmers produce crops and rear livestock simultaneously. Crop production and livestock husbandry were synergetic livelihoods of the rural farm households in Ethiopia. Crop production is important to get feed for animals, in turn; livestock production is an important means of draft power and organic manure. Asset ownership in rural Ethiopia, such as ownership of livestock, is an integral part of smallholder farmers' production systems. Livestock is considered as an asset that could be used either in the production process or be exchanged for cash to purchase agricultural production inputs i.e., improved seed, fertilizer, herbicide, etc. whenever the need arises. The area was characterized as a subsistence farming system in which all the farm operations such as land preparation, planting, and trashing were performed by animals. Also, livestock provides manure and draft power for farm operations and serves as precautionary savings given imperfect financial markets. Further, households with a larger number of livestock units have more liquid resources available to them for investing in new agricultural technologies. In turn, crop production is important to get feed for animals. Crop residue especially pulse residue is an important and expensive source of feed for farmers in the study area. Farmers were interested in adopting improved varieties with higher biomass yields to supplement their animal feed. After grain yield, biomass yield is the most critical parameter for farmers when selecting varieties. Previous research has shown that improved faba bean varieties outperform local landraces in terms of biomass yield (see for example Kassa et al. 2020). A higher degree of diversification i.e., an average crop-livestock diversification index of 0.57 was observed in the area (Mekuria and Mekonnen 2018). Further previous studies pointed out that households who practice crop-livestock systems have improved $50 \%$ of productivity and farm income in the highlands of Ethiopia compared to smallholders that only raise crops (Liniger et al. 2011). Barley, faba bean, field pea, wheat, vegetables, potatoes, lentil, linseed, and oats were the main crops grown, while poultry, dairy farming, sheep and goat rearing, and beef fattening were identified as the major sources of livelihoods from the livestock sector. In general, crop-livestock integration contributes to livelihoods, household food security, and biodiversity conservation.

Access to market information does not influence the choice to adopt but accessed household heads allocate more land to improved cultivars. Access to market information is positively related to the adoption level of improved faba bean cultivars, suggesting that having information on agricultural inputs and output market price enhances a household's ability or interest in adopting new agricultural technologies. This is because the faba bean was the only cash crop for smallholder farmers in the highland areas, and better market prices for improved cultivars highly attracted farmers to use improved cultivars to improve production and productivity. Hence, having access to market information i.e., on when, where, and which quantities to supply, and at what prices lead to better agricultural terms of trade in favor of the farmers which ultimately should increase the purchasing power of farmers to procure improved faba bean seed. Many poor communities lack not only access to the means of increased production, but also lack outlets for that increased production. Without external markets able to absorb increased production, excess crops flood the local market and drive down prices. The result showed that over $73 \%$ of the respondents have access to market information. Neighbor farmers, local traders, and own assessments directly at the marketplace are the major sources of market information for smallholder farmers in the study area. This result was found consistent with the findings of Kiiza et al. (2011), who reported that access to market information has a positive and significant impact on the level of output prices received and the intensity of adoption of improved maize. Gezimu et al. (2019) also reported that market information is positively and significantly associated with both the decision and intensity of adoption of improved maize varieties. 


\section{Conclusion and Recommendations}

The improved seed is one of the most important sources of innovation, particularly in resource-constrained small farm environments. Increasing the quality of seeds can increase the yield potential of the crop many times over. Thus, it is one of the most economical and efficient inputs for agricultural development. The responses of all other inputs depend to a large extent upon the quality of seeds used. Accordingly, the findings of the study pointed out that the adoption rate of improved faba bean seed at the household level was low, i.e., 23\%. This implies that the majority of rural households depended on their local landraces. The estimated Double-hurdle econometric model result revealed that farmers with smaller family size, farmers who had awareness about the existing improved faba bean varieties and closer contact with the extension system is more likely to adopt new technology. Similarly, farmers with larger livestock holding and having access to input and output market price information are positively related to the proportion of the area of land devoted to improved faba bean varieties.

In the end, the results of this study suggested that development policies and program interventions can be important for improving and strengthening the agricultural extension service. The result underscores the need for research and extension programs to be sensitive to the needs of farmers when developing and disseminating technologies that are relevant to their agroecology. At the same time, the availability of improved seed proved to be a major constraint for adoption, a fact that calls for improvements in improved seed delivery systems to effectively cope with the demands of small farmers.

\section{Abbreviations}

ATA: Agricultural transformation agency; CSA: Central statistical agency; FTC: Farmer training center; Ha: Hectare; HHs: Households; ICARDA: International center for agricultural research in the dry areas; MoA: Ministry of agriculture; MoANR: Ministry of agriculture and natural resource; MoARD: Ministry of agriculture and rural development; SPMC: Seed producer and marketing cooperative; TLU: Tropical livestock unit.

\section{Acknowledgements}

The authors gratefully acknowledge Amhara Agricultural Research Institute and Integrated Seed Sector Development Project Bahir Dar University for providing the financial support of the research work. We also sincerely thank enumerators, the members of the sample farm households, and key-informants for their valuable cooperation which all showed during data collection. Furthermore, we also thank the Debre Birhan Research Center Socio-Economic and Research Extension Directorate, staff.

\section{Authors' contributions}

The research design was conceived by the corresponding author together with other authors. YK carried out the data collection, data entry, performed the statistical analysis, and drafted the manuscript. AG and DA read and revised the manuscript. All authors read and approved the final manuscript.
Funding

Both the Amhara Agricultural Research Institute (ARARI) and the Integrated Seed Sector Development Project (ISSD) Bahir Dar University provided funding for this study.

\section{Availability of data and materials}

The data sets used and analyzed during the current study are available from the corresponding author on reasonable request.

\section{Declarations}

Ethics approval and consent to participate

Not applicable.

\section{Consent for publication}

Not applicable.

\section{Competing interests}

The authors declare that they have no competing interests.

\section{Author details}

${ }^{1}$ Debre Birhan Agricultural Research Center, Amhara Agricultural Research Institute, Debre Birhan, Ethiopia. ${ }^{2}$ Bahir Dar University College of Agriculture and Environmental Sciences, Bahir Dar, Ethiopia.

Received: 9 December 2019 Accepted: 8 June 2021

Published online: 26 June 2021

\section{References}

Abebe T, Birhane T, Nega Y, Workineh A. The Prevalence and importance of faba bean diseases with special consideration to the newly emerging " Faba Bean Gall " in Tigray Ethiopia. Discourse J Agric Food Sci. 2014;2(2):33-8.

Abera HB. Adoption of improved tef and wheat production technologies in crop-livestock mixed systems in northern and western Shewa zones of Ethiopia. Ph.D. Thesis [dissertation]. Pretoria, South Africa: University of Pretoria; 2008. http://hdl.handle.net/2263/25364.

Agegnehu G, Fessehaie R. Response of faba bean to phosphate fertilizer and weed control on nitisols of Ethiopian highlands. Ital J Agron. 2006;1(2):281. https://doi.org/10.4081/ija.2006.281.

Alemaw AT. Impact of Improved Maize Varieties Adoption on Smallholder Farmers Marketed Maize Surplus in Oromia Regional State, Ethiopia. Master's Thesis [dissertation]. Morogoro, Tanzania: Sokoine University of Agriculture; 2014. http://www.suaire.sua.ac.tz/handle/123456789/592.

Alemu D, Rashid S, Tripp R. Seed system potential in ethiopia; constraints and opportunities for enhancing the seed sector. Addis Ababa: International Food Policy Research Institute; 2010.

Alene AD, Poonyth D, Hassan RM. Determinants of adoption and intensity of use of improved maize varieties in the central highlands of Ethiopia: a Tobit analysis. Agrekon. 2000;39(4):633-43. https://doi.org/10.1080/03031 853.2000.9523679.

Ali A, Abdulai A. The adoption of genetically modified cotton and poverty reduction in Pakistan. J Agric Econ. 2010;61(1):175-92. https://doi.org/10. 1111/j.1477-9552.2009.00227.x.

Anteneh A, Yohannes E, Mesganaw G, Solomon G, Getachew T. Survey of faba bean (Vicia faba L.) diseases in major faba bean growing districts of North Gondar. Afr J Plant Sci. 2018;12(2):32-6. https://doi.org/10.5897/ajps2016. 1615.

Asfaw S, Shiferaw B, Simtowe F, Gebretsadik HM. Agricultural technology, seed access constraints and commercialization in Ethiopia. J Dev Agric Econ. 2011;3(9):436-47

Asfaw S, Shiferaw B, Simtowe F, Lipper L. Impact of modern agricultural technologies on smallholder welfare: evidence from Tanzania and Ethiopia. Food Policy. 2012;37(3):283-95. https://doi.org/10.1016/j.foodpol.2012. 02.013. 
ATA (Agricultural Transformation Agency). . Five-Year Vision and Roadmap of Interventions to Transform the Ethiopian Seed System. Addis Ababa: Agricultural Transformation Agency; 2011.

ATA (Agricultural Transformation Agency) and MoA (Ministry of Agriculture). Seed System Development Strategy: Vision, systematic Challenges, and prioritized interventions: Working strategy document. Addis Ababa: Ethiopia; 2013.

Atilaw A. A Baseline Survey on the Ethiopian Seed Sector. Submitted to the African Seed Trade Association. Addis Ababa: Ethiopia; 2010.

Atilaw A, Korbu L. Recent development in seed systems of Ethiopia. In: Alemu D, Kirub A, Shiratori K, editors. Improving farmers access to seed. Addis Ababa: Ethiopian Institute of Agricultural Research; 2011.

Awesa DD. Does adoption of quncho tef increases farmers' crops income? evidence from small holder farmers in Wayu Tuqa district, Oromia regional state Ethiopia. J Econ Sustain Dev. 2015;6(17):20-35.

Beshir H, Emana B, Kassa B, Haji J. Determinants of chemical fertilizer technology adoption in Northeastern highlands of Ethiopia: the double hurdle approach. J Res Econ Int Financ. 2012;1 (2):39-49.

Biagini B, Kuhl L, Gallagher KS, Ortiz C. Technology transfer for adaptation. Nat Clim Chang. 2014:4(9):828-34. https://doi.org/10.1038/nclimate2305.

Bishaw Z, Van Gastel AJG. ICARDA's seed-delivery approach in less favorable areas through village-based seed enterprises: conceptual and organizational issues. J New Seeds. 2008;9(1):68-88. https://doi.org/10.1080/ 15228860701879331

Bitew B. Survey and identification of new faba bean disease (Kormid) in the highlands of north Shewa Ethiopia. Aust J Ind Res. 2015;3(1):561-3.

Bitew B, Tigabe A. Management of faba bean gall disease (Kormid) in North Shewa. Adv Crop Sci Tech. 2016. https://doi.org/10.4172/2329-8863. 1000225

Challa M, Tilahun U. Determinants and impacts of modern agricultural technology adoption in West Wollega: the case of Gulliso district. J Biol Healthc. 2014;4(20):178-90.

Chandio AA, Yuansheng J. Determinants of adoption of improved rice varieties in northern Sindh Pakistan. Rice Sci. 2018;25(2):103-10. https://doi.org/10, 1016/j.rsci.2017.10.003.

Cragg JG. Some statistical models for limited dependent variables with application to the demand for durable goods. Econometrica. 1971:39(5):829-44.

CSA. The Federal Democratic Republic of Ethiopia Central Statistical Agency Agricultural Sample Survey 2015/2016 (2008 E.C) Report on Area and Production of Major Crops (Private Peasant Holdings Meher Season). Addis Ababa: Statistical Bulletin; 2016

CSA. The Federal Democratic Republic of Ethiopia Central Statistical Agency. Agricultural Sample Survey 2017/18 (2010 E.C.) Report on Area and Production for Major Crops (Private Peasant Holdings Meher Season). Addis Ababa: Statistical Bulletin; 2018a.

CSA. (The Federal Democratic Republic of Ethiopia Central Statistical Agency). Key Findings of the 2017/18 (2010 E.C.). Addis Ababa: Agricultural Sample Surveys; 2018b.

Dadi L, Burton M, Ozanne A. Duration analysis of technological adoption in Ethiopian agriculture. J Agric Econ. 2004;55(3):613-31. https://doi.org/10. 1111/j.1477-9552.2004.tb00117.x.

Dadi L, Regassa S, Fikre A, Mitiku D. Adoption of Improved Chickpea Varieties in the Central Highlands of Ethiopia. Addis Ababa: Ethiopian Institute of Agricultural Research; 2005.

Debela C, Negera A, Abebe Z, Tola M. Assessment of the occurrence and prevalence of faba bean gall (Olpidium viciae) in Western highlands of Oromiya Ethiopia. J Nat Sci Res. 2017;7(5):2225-921.

Detre JD, Mark TB, Mishra AK, Adhikari A. Linkage between direct marketing and farm income : a double-hurdle approach. Agribusiness. 2011;27(1):19-33. https://doi.org/10.1002/agr.20248.

Diagne A, Demont M. Taking a new look at empirical models of adoption: average treatment effect estimation of adoption rates and their determinants. Agric Econ. 2007;37:201-10. https://doi.org/10.1111/j.1574-0862. 2007.00266.x

Emiola IA, Gous RM. Nutritional evaluation of dehulled faba bean (Vicia faba CV. Fiord) in feeds for weaner pigs. SA J Anim Sci. 2011;41 (2):79-86. https://doi.org/10.4314/sajas.v41i2.71010.

Feder G, Just R, Silberman D. Adoption of Agricultural Innovations in Developing Countries : A Survey. Econ Dev Cult Change. 1985;33(2):255-98
Feder G, Just R, Silberman D. Adoption of agricultural innovations in developing countries: a survey. Econ Dev Cult Change. 1985;2(33):255-95. https:// doi.org/10.1086/451461.

Foster AD, Rosenzweig MR. Microeconomics of technology adoption. Annu Rev Econom. 2010;2(1):395-424. https://doi.org/10.1146/annurev.econo mics.102308.124433.

Gaur CP, Tripathi S, Cll G, Gv RR, Hc S, Pande S. Chickpea Seed Production Manual. In: International Crops Research Institute for the Semi-Arid Tropics. Patancheru, AP: India, 2010.

Gezimu G, Isoda H, Bahadur D, Amekawa Y. Gender differences in the adoption of agricultural technology : the case of improved maize varieties in southern Ethiopia. Womens Stud Int Forum. 2019;76:102264. https://doi. org/10.1016/j.wsif.2019.102264.

Hailu BK, Abrha BK, Weldegiorgis KA. Adoption and impact of agricultural technologies on farm income: evidence from Southern Tigray, Northern Ethiopia. Int J Foodand Agric Econ. 2014;2(4):91-106. https://doi.org/10. 2174/157340207779815581.

Hailu E, Getaneh G, Sefera T, et al. Faba bean gall; a new threat for faba bean (Vicia faba) production in Ethiopia. Adv Crop Sci Technol. 2014. https:// doi.org/10.4172/2329-8863.1000144.

HarvestChoice. Tropical Livestock Units (TLU 2005). International Food Policy Research Institute Washington, DC., and University of Minnesota, St. Paul: MN, 2015.

Kassa Y, Ayele T, Worku Y, Teferra B. Participatory evaluation of faba bean gall disease (Olpidium viciae) management options in the highland disease hotspot areas of South-Eastern Amhara Region, Ethiopia: an integrated approach. Cogent Food Agric. 2020. https://doi.org/10.1080/23311932. 2020.1801216.

Kassie M, Shiferaw B, Muricho G. Agricultural technology, crop income, and poverty alleviation in Uganda. World Dev. 2011;39(10):1784-95. https:// doi.org/10.1016/j.worlddev.2011.04.023.

Kemal A, Gemechu K, Seid A, Malhotra R, Beniwal S, Makkouk K, Halila MH. Food and Forage Legumes of Ethiopia: Progress and prospects. In: Proceedings of a Workshop on Food and Forage Legumes, 22-26 September 2003. Addis Ababa: Ethiopia, 2003.

Kiiza B, Pederson G, Lwasa S. The role of market information in adoption of agricultural seed technology in rural Uganda. Int J ICT Res Dev Africa. 2011:2(1):29-46.

Kothari CR. Research methodology methods and techniques. New Delhi: New Age International (P) Ltd Publishers; 2004

Krishnan P, Patnam M. Neighbors and extension agents in Ethiopia: who matters more for technology adoption? Am J Agric Econ. 2014:96(1):308-27.

Langyintuo AS, Mungoma C. The effect of household wealth on the adoption of improved maize varieties in Zambia. Food Policy. 2008;33(6):550-9. https://doi.org/10.1016/j.foodpol.2008.04.002.

Liniger H, Studer RM, Hauert C, Gurtner M. Sustainable Land Management in Practice-Guidelines and Best Practices for Sub-Saharan Africa. TerrAfrica, World Overview of Conservation Approaches and Technologies (WOCAT) and Food and Agriculture Organization of the United Nations (FAO), Rome: Italy, 2011

Loevinsohn M, Sumberg J, Diagne A. Under what circumstances and conditions does the adoption of technology result in increased agricultural productivity? London: EPPI-Centre, Social Science Research Unit, Institute of Education, University of London; 2012.

Malunga LN, Bar-El Dadon S, Zinal E, Berkovich Z, Abbo S, Reifen R. The potential use of chickpeas in development of infant follow-on formula. Nutr J. 2014;13(1):1-6. https://doi.org/10.1186/1475-2891-13-8.

Mason NM, Smale M. Impacts of subsidized hybrid seed on indicators of economic well-being among smallholder maize growers in Zambia. Agric Econ. 2013;44:659-70. https://doi.org/10.1111/agec.12080.

Mekuria W, Mekonnen K. Determinants of crop-livestock diversification in the mixed farming systems: evidence from central highlands of Ethiopia. Agric Food Secur. 2018;7(60):1-15. https://doi.org/10.1186/ s40066-018-0212-2.

Messrs M, Zappacosta WI, Robinson NE, Scott Ronchini NL. FAO/WFP Crop and Food Supply Assessment Mission to Ethiopia: Special Report. Food and Agriculture Organization of the United Nations and World Food Programme, Rome: Italy, 2007. http://www.fao.org/giews. 
MoA (Ministry of Agriculture). Crop Variety Register Issue No. 21. Ministry of Agriculture plant variety release, protection, and seed quality control directorate. Addis Ababa: Ethiopia, 2018.

MoARD (Ministry of Agriculture and Rural Development). Animal and Plant Health Regulatory Directorate: Crop Variety Register Issue No. 11. Addis Ababa: Ethiopia, 2008

Rashid S, Yirga C, Behute B, Lemma S. Pulses Value Chain in Ethiopia Constraints and Opportunities for Enhancing Exports: Working Paper. International Food Policy Research Institute. NW, Washington DC: USA, 2010.

Ricker-Gilbert J, Jayne TS, Chirwa E. Subsides and crowding out: a double-hurdle model of fertilizer demand in Malawi. Amer J Agr Econ. 2011;93(1):2642. https://doi.org/10.1093/ajae/aaq122.

Ronner $\mathrm{E}$, and Giller KE. Background information on agronomy, farming systems, and ongoing projects on grain legumes in Ethiopia. 2012. p 33. https://www.n2africa.org/

Sarker SK, Rashid S, Sharmin M, Haque MM, Sonet SS, Nur-Un-Nabi M. Environmental correlates of vegetation distribution in tropical Juri forest Bangladesh. Trop Ecol. 2014;55(2):177-93.

Shiferaw BA, Kebede TA, You L. Technology adoption under seed access constraints and the economic impacts of improved pigeon pea varieties in Tanzania. Agric Econ. 2008;39(3):309-23. https://doi.org/10.1111/j. 1574-0862.2008.00335.x.

Storck H, Emana B, Adenew B, Borowiecki A, Shimelis W Hawariat. Farming Systems and Farm Management Practices of Smallholders in the Hararghe Highlands: A Baseline Survey. Farming System and Resource Economics in the Tropics, 1991

Sunding D, Zilberman D. The agricultural innovation process. Handb Agric Econ. 2001;1:207-61. https://doi.org/10.1016/S1574-0072(01)10007-1.

Tambo JA, Abdoulaye T. Climate change and agricultural technology adoption : the case of drought-tolerant maize in rural Nigeria. Mitig Adapt Strateg Glob Change. 2012;17:277-92. https://doi.org/10.1007/ s11027-011-9325-7.

Tekalign A, Derera J, Sibiya J, Fikre A. Participatory assessment of production threats, farmers' desired traits and selection criteria of faba bean (Vicia faba L.) varieties: opportunities for faba bean breeding in Ethiopia. Indian J Agric Res. 2016;50(4):295-302. https://doi.org/10.18805/ijare.v0iOF. 11180.
Thijs R, Auke B, Daphne W, Dawit K, Wannes D. Business Opportunities Report Oilseeds and pulses \#5 in the series written for the Ethiopian Netherlands business event 5-6 November 2015, Rijswijk: The Netherlands, 2015.

Tobin J. Estimation of relationships for limited dependent variables. Econometrica. 1958;26(1):24-36. https://doi.org/10.2307/1907382.

Vandercasteelen J, Dereje M, Minten B, Taffesse AS. Labour, profitability and gender impacts of adopting row planting in Ethiopia. Eur Rev Agric Econ. 2018;45(4):471-503. https://doi.org/10.1093/erae/jby001.

Verkaart S, Munyua BG, Mausch K, Michler JD. Welfare impacts of improved chickpea adoption: a pathway for rural development in Ethiopia? Food Policy. 2017;66:50-61. https://doi.org/10.1016/j.foodpol.2016.11.007.

Weyessa BG. A double-hurdle approach to modeling of improved tef technologies adoption and intensity use in case of Diga district of East Wollega zone. Glob J Environ Res. 2014;8(3):41-9. https://doi.org/10.5829/idosi. gjer.2014.8.3.1106.

White DS, Labarta RA, Leguia EJ. Technology adoption by resource-poor farmers: considering the implications of peak-season labor costs. Agric Syst. 2005;85:183-201. https://doi.org/10.1016/j.agsy.2004.07.018.

Yigezu YA, Tizale CY, Aw-Hassan A. Modeling Farmers' Adoption Decisions of Multiple Crop Technologies: The Case of Barley and Potatoes in Ethiopia. In: International Association of Agricultural Economists 2015 Conference, August 9-14, Milan: Italy, 2015. https://econpapers.repec.org/RePEc:ags: iaae 15:211867

Yirga C, Atnafe Y, Awhassan A. A multivariate analysis of factors affecting adoption of improved varieties of multiple crops: a case study from Ethiopian highlands. Ethiop J Agric Sci. 2015;25(2):29-45.

Zeng D, Alwang J, Norton G, Jaleta M, Shiferaw B, Yirga C. Land ownership and technology adoption revisited: improved maize varieties in Ethiopia. Land Use Policy. 2017;2018(72):270-9. https://doi.org/10.1016/j.landusepol. 2017.12.047.

\section{Publisher's Note}

Springer Nature remains neutral with regard to jurisdictional claims in published maps and institutional affiliations.
Ready to submit your research? Choose BMC and benefit from:

- fast, convenient online submission

- thorough peer review by experienced researchers in your field

- rapid publication on acceptance

- support for research data, including large and complex data types

- gold Open Access which fosters wider collaboration and increased citations

- maximum visibility for your research: over 100M website views per year

At BMC, research is always in progress.

Learn more biomedcentral.com/submissions 